\title{
EFFECT OF LEAF RUST ON THE YIELD OF RESISTANT WHEATS ${ }^{1}$
}

\author{
D. J. Samborski and B. Peturson ${ }^{2}$ \\ Canada Department of Agriculture, Winnipeg, Manitoba \\ [Received for publication March 3, 1960]
}

\begin{abstract}
Heavy infection of leaf rust initiated at an early stage of plant development materially reduced the yield, kernel weight and bushel weight of one susceptible and thrce resistant varieties of wheat. The yield loss in the susceptible variety was 58 per cent whereas in the resistant varieties it ranged from 12 to 28 per cent. The results indicate a direct relation between the density of inoculum and the amount of necrosis on varieties that are resistant but not immune.
\end{abstract}

\section{INTRODUCTION}

Effective leaf rust resistance prevents yield loss by inhibiting reproduction and subsequent spread of the pathogen. In many instances, the necrotic areas associated with resistance involve the destruction of a certain amount of leaf tissue around each infection. Within a large area planted to resistant varieties, the spore population is kept at a low level and the total amount of dead tissue resulting from infection is also low. However, when resistant varieties are grown in experimental plots, the proximity of susceptible varieties provides a constant and heavy supply of inoculum and considerable destruction of leaf tissue of resistant varieties may occur. The authors have studied resistant varieties under these conditions in order to determine the yield losses resulting from such leaf destruction. It should be emphasized that this is an agronomically abnormal situation and the results do not give a true appraisal of the practical performance of the resistant varieties under field conditions.

\section{METHODS}

Four varieties were included in the test: Thatcher, highly susceptible to leaf rust (Puccinia recondita Rob. ex. Desm. f. sp. tritici), Selkirk, moderately resistant to leaf rust, and two highly resistant hybrids, Thatcher ${ }^{7}$ $\mathrm{x}$ Frontana and Selkirk ${ }^{8} \mathrm{x}$ Exchange. Appreciable necrosis is associated with infections on Selkirk and the resistant hybrids. There were twelve plots of each variety, each consisting of four rod rows. Half of the plots of each variety were kept almost rust free by spraying them with Zineb (Dithane-Z78) (3) twice weekly and after every heavy rain from the time that rust first appeared in the plots until just before harvest. These plots received a total of eleven sprays. The remaining plots were not treated and became rusted by naturally occurring leaf rust inoculum. At maturity, the two centre rows were harvested and data were taken on yield, 1000kernel weight, and bushel weight. The percentages of leaf rust and percentages of necrotic leaf areas were estimated while the leaves were still partially green. Diseases other than leaf rust were absent or insignificant.

\section{RESULTS AND DISCUSSION}

Leaf rust inoculum arrived early in the growing season and the subMan.

${ }^{1}$ Contribution No. 48 from the Research Station, Canada Department of Agriculture, Winnipeg, Plant Pathology Laboratory. 
TABLE 1. - EFFECT OF LEAF RUST ON THE YIELD, KERNEL WEIGHT AND BUSHEL WEIGHT OF FOUR WHEAT VARIETIES

\begin{tabular}{|c|c|c|c|c|c|c|}
\hline Variety & Treatment & $\begin{array}{l}\text { Necrotic } \\
\text { or chlorotic } \\
\text { area of } \\
\text { leaf } \\
(\%)\end{array}$ & $\begin{array}{c}\text { Severity of } \\
\text { infection - } \\
\text { sporulating } \\
\text { pustules } \\
(\%)\end{array}$ & $\begin{array}{c}\text { Av. } \\
\text { yield } \\
\text { per acre } \\
\text { (bu.) }\end{array}$ & $\begin{array}{c}\text { Av. } \\
\text { weight } \\
\text { per } 1000 \\
\text { kernels } \\
\text { (gm.) }\end{array}$ & $\begin{array}{l}\text { Bushel } \\
\text { weight } \\
\text { (1b.) }\end{array}$ \\
\hline Thatcher & $\begin{array}{l}\text { Sprayed } \\
\text { Unsprayed }\end{array}$ & - & $\begin{array}{r}2 \mathrm{~S} \\
100 \mathrm{~S}\end{array}$ & $\begin{array}{l}33.6 \\
14.0\end{array}$ & $\begin{array}{l}29.9 \\
22.7\end{array}$ & $\begin{array}{l}58.8 \\
56.5\end{array}$ \\
\hline $\begin{array}{l}\text { Thatcher } \\
x \\
\text { Frontana }\end{array}$ & $\begin{array}{l}\text { Sprayed } \\
\text { Unsprayed }\end{array}$ & $\begin{array}{l}\text { tr. } \\
60\end{array}$ & $3 \stackrel{\text { tr. }}{R}$ & $\begin{array}{l}34.8 \\
24.8\end{array}$ & $\begin{array}{l}30.4 \\
24.5\end{array}$ & $\begin{array}{l}58.5 \\
57.8\end{array}$ \\
\hline Selkirk & $\begin{array}{l}\text { Sprayed } \\
\text { Unsprayed }\end{array}$ & $\begin{array}{l}\text { tr. } \\
40\end{array}$ & $\begin{array}{r}1 \mathrm{MR} \\
20 \mathrm{MR}\end{array}$ & $\begin{array}{l}33.6 \\
24.0\end{array}$ & $\begin{array}{l}37.8 \\
32.0\end{array}$ & $\begin{array}{l}56.8 \\
55.5\end{array}$ \\
\hline Selkirk ${ }^{8}$ & Sprayed & tr. & tr. & 29.8 & 37.1 & 56.3 \\
\hline $\begin{array}{c}\mathbf{x} \\
\text { Exchange }\end{array}$ & Unsprayed & 30 & $1 \mathrm{R}$ & 26.2 & 31.6 & 55.3 \\
\hline & \multicolumn{3}{|c|}{ Necessary difference, $5 \%$ level } & 5.9 & 1.14 & 1.0 \\
\hline
\end{tabular}

sequent build-up on susceptible varieties was rapid. The varieties in this experiment were planted rather late and the combination of late planting and a rapid and early build-up of the pathogen resulted in very heavy infection of leaf rust at an early stage of plant development.

The results of the field experiments are summarized in Table 1. Zineb sprays gave excellent control of leaf rust on the susceptible variety and practically prevented necrosis on the resistant varieties. 'The rust readings shown in Table 1 were recorded at flowering time and leaf destruction progressed rapidly until the leaves were largely non-functional. The rate of leaf destruction was particularly rapid on Thatcher $^{7} \times$ Frontana.

The resistant varieties suffered substantial yield losses. In fact, in two varieties, the yield loss was one-half that suffered by the susceptible variety. It is probable that the yield reductions in the resistant varieties were due to destruction of photosynthetic tissue. Destruction of photosynthetic tissue would also affect the yields of susceptible varieties. In addition, diversion of nutrients from the host to the fungus must be of considerable importance in affecting the yields of susceptible varieties. This appears to be particularly important during the period when seed set is being determined.

It is generally agreed that leaf rust causes yield losses by reducing the number of kernels per head as well as reducing kernel weight $(1,2,4,5)$. The stage of development reached by the plants before rust becomes severe determines whether reduced kernel production or reduced kernel weight is responsible for the major reduction in yield (5). In the present investigation, leaf rust was severe at a very early stage of plant development. Although the number of kernels produced per head was not estimated, the yield and kernel weight data indicate that reduced kernel production must have been an important factor in reducing the yield, particularly of the susceptible variety. 
The present results show that yield tests with resistant varieties will be influenced by the proximity of susceptible plants. Under these conditions, the great advantage of the resistant variety, that of limiting the reproduction of the fungus, is largely nullified. However, these observations are not universally applicable since Caldwell et al. (1) found that a resistant variety used in their investigations did not suffer any yield loss. The extent to which the yield of a resistant variety might be affected under these conditions would in part be influenced by the type of resistance involved since the amount of necrosis resulting from each infection would determine the rate of leaf destruction. Certainly the present results show that extensive leaf necrosis caused by leaf rust diminished the yield, 1000kernel weight, and bushel weight of the varieties which were studied.

\section{REFERENCES}

1. Caldwell, R. M., H. R. Kraybill, J. T. Sullivan, and L. E. Compton. Effect of leaf rust (Puccinia triticina) on yield, physical characters, and composition of winter wheats. J. Agr. Research 48:1049-1071. 1934.

2. Chester, K. W. The cereal rusts. Chronica Botanica Co., Waltham, Mass. 1946.

3. Forsyth, F. R., and B. Peturson. Control of stem and leaf rust of wheat with fungicides. Can. J. Plant Sci. 38:173-180. 1958.

4. Johnston, C. O. Effect of leaf rust infection on yield of certain varieties of wheat. J. Amer. Soc. Agron. 23:1-12. 1931.

5. Peturson, B., M. Newton, and A. G. O. Whiteside. The effect of leaf rust on the yield and quality of wheat. Can. J. Research, C, 23:105-114. 1945. 